\title{
Identification of Immunotopes against Mycobacterium leprae as Immune Targets Using PhDTm- 12mer Phage Display Peptide Library
}

\author{
Marzieh Ferdosian ${ }^{1}$, Mohammad Reza Khatami ${ }^{2}$, Ziba Vaise Malekshahi ${ }^{3}$, Ali \\ Mohammadi $^{2}$, Hamed Haddad Kashani ${ }^{4}$ and Mohammad Barat Shooshtari ${ }^{2 *}$ \\ ${ }^{1}$ Medical Biotechnology Department, Biotechnology Research Center, Pasteur Institute, ${ }^{2}$ Biotechnology Research Center, \\ Institute of Science and New Technologies, ${ }^{3}$ Department of Medical Biotechnology, School of Advanced Medical Sciences and \\ Technologies, Tehran University of Medical Sciences, ${ }^{4}$ Anatomical Sciences Research Center, Kashan University of Medical \\ Sciences, Kashan, Iran
}

*For correspondence: Email: behzadshoshtary@gmail.com; Tel: +989123146970

Received: 20 February 2015

Revised accepted: 8 June 2015

\begin{abstract}
Purpose: To determine the surface epitopes of Mycobacterium leprae (M. leprae) and evaluate their efficacy in the production of anti-M. leprae antibodies in an animal model.

Methods: Blood samples were obtained from 34 patients suffering from lepromatous leprosy. Antibodies were obtained from the samples, semi-purified and used to coat the wells of ELISA microplate, and M13 random-peptides library was added to the wells. After four rounds of panning, three clones were isolated and their peptide mimotopes were sequenced. Western blot was used to evaluate the interaction of the isolated mimotopes.

Results: Three selective clones were tested by direct enzyme-linked immunosorbent assay (ELISA) and western blot. anti-leprae antibodies in various dilutions and were found to be serological active. Sequencing of the isolated peptides showed identities between the two clones that were able to successfully induce anti-Leprae humoral response in mice.

Conclusion: The findings indicate that the isolated peptides can potentially be used for early diagnosis. However, further research is required to improve their potency as new vaccines against leprosy.
\end{abstract}

Keywords: Bacteriophage, Vaccine, Leprosy, Mycobacterium leprae, Random peptide phage display library

Tropical Journal of Pharmaceutical Research is indexed by Science Citation Index (SciSearch), Scopus, International Pharmaceutical Abstract, Chemical Abstracts, Embase, Index Copernicus, EBSCO, African Index Medicus, JournalSeek, Journal Citation Reports/Science Edition, Directory of Open Access Journals (DOAJ), African Journal Online, Bioline International, Open-J-Gate and Pharmacy Abstracts

\section{INTRODUCTION}

Leprosy is a chronic granulomatous bacterial infection with $M$. leprae that principally affects the skin and the peripheral nervous system [1-2]. In endemic areas, the incidence of leprosy is estimated to be about 4 to 6 cases per thousand. The lipid-rich cell wall of pathogenic bacteria are likely responsible for their resistance and enable bacteria to escape from host defense mechanism.

Leprosy treatment is difficult due to slow growth rate of the bacteria and long incubation period (average of 3-10 years). Additionally, multiple relapse and the emergence of drug-resistant strains have made the treatment more challenging. Such clinical prognosis correlates with the level of cell-mediated immunity (CMI) 
against $M$. leprae. Antibody responses are great in lepromatous patients, indicating that humoral immunity does not contribute to the host defense [6].

On the other hand, full assessment of $M$. leprae antigenic structure is not possible due to lack of bacterial growth in culture media that has major contribution in the absence of suitable vaccine against leprosy [4]. The World Health Organization's effort to eliminate leprosy by 2000 was based on important advances achieved in anti-mycobacterial therapy in the 1980s. Although over the last decade, the dramatic reduction in prevalence of leprosy has been reported in most of the endemic countries, but its incidence rate is also high [3,5]. In this context, the IDEAL consortium Initiative for Diagnostic and Epidemiological Assays for Leprosy was established in 2004 and represents an international task-force that brings together researchers from endemic and non-endemic countries and aiming at the concerted development of diagnostic tests for early diagnosis of leprosy [5]. Identification of molecular markers improves epidemiological knowledge and transmission of leprosy that leads to intervention designing for prevention of the disease $[3,7]$.

Display systems based on bacteriophages are widely used to assess different proteins and antibodies developed for identification of pathogenic bacteria [8-10]. A phage library that expresses random short peptide sequences on the surface of filamentous phage represents one of the biotechnological tools that could be helpful in amino acid sequence identification of various antigenic epitopes [11-13]. Panning the peptide phage library against a specific antibody results in isolation and identification of desired epitopes and their amino acid sequence and also determining the nucleotide sequence of genes expressing peptides on the phage surface $[11,13,14]$.

In this research, the M13 random peptide phage library was used to detect the surface antigen epitopes of leprosy bacterium [15]. In addition to high efficiency, phage display systems are easy to work with and require no advanced techniques, expensive equipment or materials [16]. Isolated phage-peptides can be used for induction of immune response without use of adjuvants [17,18]. M13 phage is a filamentous bacteriophage and is one the most used display systems [16]. One of the important and unique features of the vectors derived from the M13 phage is their potential for expressing short random peptide sequences on one of their coat proteins [16].

In this study, specific anti-M. leprae antibodies isolated from patients were used in panning against peptide phage library, This method can help to identify the functional epitope sequences and may contribute to development of a diagnostic assay or vaccines against leprosy $[15,19]$.

\section{EXPERIMENTAL}

\section{Library preparation}

The Ph.D. ${ }^{\mathrm{TM}}-12$ Phage Display Peptide Library is based on a combinative library of random peptides fused on a minor coat protein (pIII) of M13 phage $[20,21]$. The peptide is linked to the plll coat protein by a spacer (Gly-Gly-Gly-Ser). The library consists of approximately $2.8 \times 10^{9}$ unique members, amplified once to yield approximately 70 copies of each sequence in 10 $\mu \mathrm{l}$ of the supplied phage.

\section{Preparation of leprosy antiserum}

Antiserum was prepared from blood samples of 34 leprosy patients in Lepromatous stage that were received from Center for Research and Training in Skin Disease and Leprosy. Plasma was separated from the blood clot after centrifugation at $1000 \mathrm{~g}$ at $4{ }^{\circ} \mathrm{C}$. Serum samples of all 34 patients were pooled together and ammonium sulfate precipitation (final concentration $45 \%$ ) was used to increase the concentration of antibodies. After addition of sodium azide, the precipitated serum was distributed in $500 \mu \mathrm{L}$ aliquots and kept at $-20{ }^{\circ} \mathrm{C}$. Protein concentration of samples were determined by the Bradford method [22].

\section{Phage titration}

The phage library was titrated before panning. Serial dilutions of phage were prepared in LB broth (1\% Yeast extract, $1 \%$ Tryptone and $1 \%$ $\mathrm{NaCl})$. Dilutions were added to E. coli ER2738 and incubated at room temperature for 5 minutes. The bacteria were mixed with Top agar (1\% Yeast extract, $1 \%$ Tryptone, $1 \% \mathrm{NaCl}$ and $0.75 \%$ Agar) and plated on LB agar containing X-Gal $(20 \mu \mathrm{g} / \mathrm{mL})$ and Isopropyl thiogalactose (IPTG) $(1 \mathrm{mM})$. The plates were incubated at 37 ${ }^{\circ} \mathrm{C}$ for $16 \mathrm{~h}$ and numbers of colonies were counted to obtain phage $\mathrm{pfu} / \mathrm{mL}$. 


\section{Screening}

The ELISA microplate wells were coated with 15 $\mu \mathrm{g}$ of leprosy antiserum in $150 \mu \mathrm{L}$ volume of 100 $\mathrm{mM}$ sodium bicarbonate buffer $(\mathrm{pH} 8)$ and incubated overnight at $4{ }^{\circ} \mathrm{C}$. The wells were washed using TBS $(50 \mathrm{mM}$ Tris- $\mathrm{Cl}, 150 \mathrm{mM}$ $\mathrm{NaCl}, \mathrm{pH} 7.5$ ) and blocked using $200 \mu \mathrm{L}$ of 100 $\mathrm{mM}$ sodium bicarbonate buffer containing $3 \%$ BSA and incubated at $37^{\circ} \mathrm{C}$ for $1 \mathrm{~h}$. Wells were then washed six times using TBS containing 0.05 $\%$ Tween 20 (TBST). A total of $4 \times 10^{10}$ Phages were diluted in $1 \mathrm{ml}$ of TBST buffer and $100 \mu \mathrm{L}$ was added to each well. The microplate was incubated at room temperature for $1 \mathrm{~h}$. The supernatant was discarded and the wells were washed 10 times with Tris-Buffered Saline and Tween 20 (TBST) buffer. For eluting the bound phages, $100 \mu \mathrm{L}$ of glycine and BSA buffer (100 $\mathrm{mM} \mathrm{HCl}$-Glycine, $\mathrm{pH}$ 2.2) was added to the wells and the plate was incubated at room temperature for 15 min. Finally, $15 \mu \mathrm{L}$ of $1 \mathrm{M}$ Tris buffer $(\mathrm{pH}$ 9.1) was added to each well for neutralization of glycine buffer.

\section{Phage multiplication}

One microliter of isolated phages was added to $200 \mathrm{~mL}$ of fresh bacterial suspensions at mid log phase and incubated for $4.5 \mathrm{~h}$ at $37^{\circ} \mathrm{C}$. It was centrifuged at $10000 \mathrm{~g}$ for $10 \mathrm{~min}$ at $4{ }^{\circ} \mathrm{C}$. The supernatant was saved and mixed with $20 \%$ (v/v) PEG/NaCl solution (16\% Polyethylene glycol in $2.5 \mathrm{M} \mathrm{NaCl}$ ) and incubated on ice for 16 h. The Phage/PEG/NaCl solution was centrifuged at $15000 \mathrm{~g}$ for $20 \mathrm{~min}$. The phage sediment was resuspended in $1 \mathrm{~mL}$ TBS solution and stored at $4{ }^{\circ} \mathrm{C}$ for further application. To obtain the highest affinity binders, panning procedure ("Screening" and "Phage multiplication" steps) was repeated three or more times. Eluted phages from previous round were used for each panning round.

\section{Clone selection}

The phages after the fourth panning round were used for selecting specific clones with high affinity obtained leprosy antiserum.

For selection of specific clone, $100 \mu \mathrm{g}$ of patient anti-serum, normal anti-serum and BSA (5 $\mathrm{mg} / \mathrm{ml}$ ) blocking buffer was separately added to the wells in duplicate and the plate was incubated $16 \mathrm{~h}$ at $4{ }^{\circ} \mathrm{C}$.

Serial dilution was prepared from phages purified from all selected clones. For each clone, $1 \times 10^{12}$ phage were diluted in a volume of $200 \mathrm{ml}$ and then diluted 12 times by a factor less than 4 , until number of phages reached $2 \times 10^{5} \mathrm{pfu} / \mathrm{mL}$.

After washing and blocking the wells, $100 \mu \mathrm{l}$ of the diluted phages were added to each well and the plate was incubated at $37{ }^{\circ} \mathrm{C}$ for $1 \mathrm{~h}$. Wells were washed and $200 \mu \mathrm{l}$ of the anti-M13 antibody (New England Biolabs, UK) diluted in the blocking buffer (1:5000) was added to each well. After $1 \mathrm{~h}$ incubation at $37^{\circ} \mathrm{C}$, the wells were washed 6 times with TBST buffer. Finally, $15 \mathrm{~min}$ after addition of the ABTS substrate (2, 2'Azinobis [3-ethylbenzothiazoline-6-sulfonic acid]diammonium salt) (Sigma, Germany) dissolved in sodium citrate buffer the resulting color was read at $405-415 \mathrm{~nm}$ by ELISA reader. The clones with high absorbance compared with the normal serum and BSA were considered as positive clones.

\section{Western blot analysis}

To confirm phage expression of the peptides, 10 $\%$ SDS-PAGE was used and the proteins transferred onto nitrocellulose membrane using a semi-dry transfer apparatus (ATTO Co. Japan), and thereafter incubated by polyclonal Anti- $M$. leprae MLMA-LAM (Rabbit antiserum, BEI Resources). The secondary antibody (HRPconjugated rabbit anti-IgG antibody, Abcam), diluted in the blocking buffer, was added. After washing the membrane with TBST for $15 \mathrm{~min}$, detection was performed using DAB (diaminobenzidine) as a substrate $[13,20]$.

\section{Animal tests}

Six weeks old Balb/c mice (15-18 g) were used to evaluate the immunogenicity and specificity of the peptide in induction of anti-M. leprae antibodies.

The experiment included 6 groups each of 5 mice. The mice in groups 1,2 and 3 were injected with $200 \mu \mathrm{l}$ of $1 \times 10^{13} \mathrm{cfu} / \mathrm{mL}$ of clone 6,9 and 10, respectively. Groups 4 and 5 were considered as positive controls and were respectively injected with $100 \mu \mathrm{g}$ of Lepromin (ML) and Mycobacterium extract (M) in $200 \mu \mathrm{L}$ PBS. Group 6 was the negative control and each mouse in the group was injected with the wild M13 bacteriophage in the same amount as groups 1 to 3 . All injections were carried out intraperitoneally. First booster was injected after 3 weeks and the rest of injections were done with 2 week intervals. The immunization process was assayed by indirect ELISA. M. leprae extract was used to coat the ELSA microplate wells. Sera obtained from the mice were used as primary antibody and anti-mouse $\lg$ antibody 
conjugated with HRP (AbCam, UK) was used as a secondary antibody.

\section{Sequence determination}

To determine the genetic sequence of the peptides, $100 \mu \mathrm{L}$ of positive sample mixed in TE buffer $\left(1 \times 10^{13} \mathrm{cfu} / \mathrm{mL}\right)$ was sequenced by primers of 12-mer Peptides of Phage Display Library kit (Biolab, England).

\section{Statistical analysis}

One-way analysis of variance (ANOVA) was used to assess differences in the binding of phage-peptide to the test serum, control serum and BSA. The data are presented as mean \pm standard deviation and compared using Duncan's multiple range tests $(p<0.01)$.

\section{RESULTS}

\section{Clone selection}

The clones were selected from the 4th round. Study of optical absorptions showed that only 3 clones namely; 1,6 , and 9 , had notable binding difference between the test serum, control serum and BSA, and showed the highest affinity toward leprosy antiserum. Results show that most clones do not show significant binding differences between the control groups, the test serum and BSA. However, significant difference was observed in comparison of the control groups and test serum in three clones 1,6 and 9 at $1 \times 10^{12}, 2.2 \times 10^{8}$ and $2 \times 10^{5}$ dilutions.

\section{Positive clones}

The size of plll coat protein was about $45 \mathrm{kDa}$ and can be seen in 45 to $65 \mathrm{kDa}$ range. There were several specific bands within that range that were not observed in the positive and negative controls. These bands are not observed in clone 6 . Indeed, clone 6 could not elicit specific anti-M. leprae antibody response in the animal tests. The lighter bands could be as a result of protein degradation during the extraction process or cross-reaction. Finally, clones 1 and 9 were accepted as positive (Figure 1).

Table 1: Analysis of ELISA results performed on test and control sera, and BSA at a dilution of $2 \times 10^{5} \mathrm{cfu} / \mathrm{mL}$

\begin{tabular}{lccccc}
\hline Subject & Source of variant & Mean square & Sum of squares & df & $\mathbf{F}_{\mathbf{C}}$ \\
\hline \multirow{2}{*}{ Patient Serum } & Between Groups (Treatment) & 1.279 & 12.793 & 10 & $171^{* *}$ \\
\cline { 2 - 6 } & Within Groups(Error) & 0.007 & 0.164 & 22 & \\
\cline { 2 - 6 } Normal Serum & Between Groups (Treatment) & 0.004 & 0.041 & 10 & 1.641 \\
\cline { 2 - 6 } & Within Groups(Error) & 0.003 & 0.055 & 22 & \\
\hline \multirow{2}{*}{ BSA } & Between Groups (Treatment) & 0.002 & 0.020 & 10 & 1.902 \\
\cline { 2 - 6 } & Within Groups(Error) & 0.001 & 0.023 & 22 & \\
\hline
\end{tabular}

*Significant at $1 \%$ probability

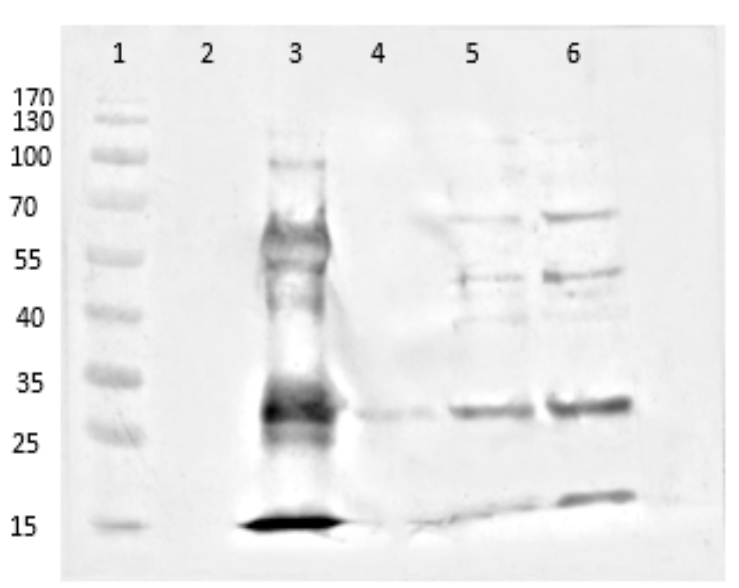

Fig 1: Western blot analysis on selected clones. Lane 1: Standard protein Marker. Lane 2: Protein extracted from wild type M13 bacteriophage. Lane 3: cell extracts of Mycobacterium Leprae. Lanes 4, 5 and 6: Protein extracts from phage clones 6, 9 and 1, respectively

\section{Animals}

Clone 6 showed immunogenicity only in one round; however, clones 1 and 9 produced specific anti-M. leprae immunity in all repeats Table 2. Groups 5 and 6 which were immunized with $\mathrm{M}$ and $\mathrm{ML}$ form respectively, were used as positive controls and were able to induce high immunity. Group 6 is the negative control group injected with wild type M13 showed no specific immune response against $M$. leprae antigens. Following the results of immunogenicity, the clones positive were sequenced. Nucleic acid sequences of clones 1 and 9 are shown in Table 3.

Phage-peptides (1, 6 and 9), Wild type M13 (10), $M$. leprae extract $(\mathrm{M})$ and Lepromine $(\mathrm{ML})$ were used to evaluate of specific immune response induction in mice. Three repeats were carried out. Clones which were able to induce anti-M. 
leprae antibodies were sequenced As shown the peptide sequence of both clones are same.

\section{DISCUSSION}

In the current study we achieved high affinity peptides (epitopes) that expressed on the surface of phage and are able to bind anti- $M$. leprae specific antibodiesFinally, two clones showed potential immunogenicity in mice. Lack of immunogenicity in the clone 6 may be because of phage mutation or immune system default of mice models that could not able to recognize this peptide as an antigen. However, clones 1 and 9 were able to induce specific antibodies which are able to react with $M$. leprae antigens, thus these mimotope peptides have potential applications as a vaccine against the disease or may be applied as a diagnostic tool for leprosy cases. Despite that the immunogenicity mechanism is unknown, the antibody titer was considerably high. Given the amount of lepromin used in this study, the immune response of the peptides was equal to those of the positive control groups. The obtained immunotopes would thus be suitable for the preparation of sub-unit vaccine candidates against leprosy, or can be used in a more complex form to include cellular immunity response. Furthermore, the monoclonal antibodies achieved against these peptides can be used for development of accurate diagnostic tests.
In this study, 11 plaques were randomly selected and analyzed for expression of foreign peptides, positive single clones sent for sequencing. Results of sequence identification in clones 1 and 9 showed that the both clones have same sequence that could explain the western blotting binding pattern. The specificity of obtained sequence was confirmed by NCBI-Blast software $[24,25]$.

Leprosy diagnosis is mainly based on symptoms and clinical studies and there is no laboratory test to diagnose or predict the disease progression in individuals at risk [26]. There are two forms of disease caused by $M$. leprae. The specific antibody titer is low in tuberculoid paucibacillary leprosy (PB) but strong Th1/IFN-y response that the role of cellular immunity (CMI) is significant. In the lepromatous multibacillary patients (MB) the antibody titer is high and the cell-mediated immunity $(\mathrm{CMI})$ is low. Thus the (PB) and (MB) laboratory tests for the leprosy diagnosis are based on measuring the cellmediated immunity and antibodies. However, the laboratory tests should detect (PB) and (MB) forms. These require proteins with specific properties. These proteins can be obtained by recombinant or synthetic techniques $[3,7]$. Production of Lepromin requires bacterial culture and animal immunization, in our study we were able to produce peptides that can induce the same immune response as Lepromin,

Table 2: Immune response against mimotope peptides in animal models

\begin{tabular}{cccccccc}
\hline Experiment repeat $\downarrow$ & Immunized with $\rightarrow$ & 1 & 6 & 9 & 10 & $\mathrm{M}$ & $\mathrm{ML}$ \\
\hline 1 & & + & - & + & - & + & + \\
2 & + & + & + & - & + & + \\
3 & & + & - & + & - & + & + \\
\hline
\end{tabular}

Table 3: DNA sequences of selected recombinant phages

\begin{tabular}{lll}
\hline Positive clone & Nucleotide acid sequence of epitope & $\begin{array}{l}\text { Amino acid sequence of } \\
\text { epitope }\end{array}$ \\
\hline Clone-1 & 5'- CTC GAG CAA TGC CAA GAA TCG -3' & LEQCQES \\
Clone-9 & 5'- CTC GAG CAA TGC CAA GAA TCG -3' & LEQCQES \\
\hline
\end{tabular}

thus the purified peptide has the potential to replace lepromin in research and therapy $[15,26]$.

The methods based on IFN-y and T-cell are not able to detect sub-clinical disease, and patients at the early stages of treatments. Moreover (PB) and $(\mathrm{MB})$ forms cannot be distinguished $[3,7]$. It is ideal to use the peptides specific to $M$. leprae, recombinant or synthesized proteins in IFN-y and T-cell methods. It is important to differentiate between the two (PB) and (MB) phases. These require access to the antigens of the bacteria which is complicated with respect to the difficulties in culturing and antigen isolation from M. leprae.

In this study, the phage clones were selected from the phage library panned against antibodies isolated from lepromatous multibacillary (MB) stages. This stage has been selected due to high levels of antibodies against the disease. Also, by accessing specific peptides, patient identification by early diagnosis of infection would be possible by evaluation of specific cellular immunity (CMI) against leprosy [3]. 
However, given the genetic diversity of people and variety in HLA classes, feasibility of the methods for producing peptides that could result in production of high affinity antibodies that leads to use of diverse and rich pool of antibodies isolated from various people to include genetic diversity [25]. Accordingly, the antibodies used for panning in this research were extracted from a total of 34 patients and pooled to include most HLA varieties.

M13 random phage peptide library was used against antibodies from leprosy patients to isolate the peptides mimicking the immunogenic epitopes of $M$. leprae antigens.

\section{CONCLUSION}

This work identifies peptides which bind with high affinity to antibodies against $M$. leprae. Following injection of peptides to the mice model, the monoclonal antibodies produced can facilitate the development of serological diagnostic kits for detection of this bacterium and disease. Furthermore, the peptide may be used for the development of a new generation of vaccines that induce both cellular and humoral anti- $M$. leprae responses.

\section{ACKNOWLEDGEMENT}

The authors would like to thank Center for Research and Training in Skin Disease and Leprosy, Tehran, Iran for preparation of blood samples.

\section{REFERENCES}

1. Warburton KL, Wakerley B. Dermatological clues to neurological diagnoses. Pract neurol 2011; 11(5): 289-295.

2. Al Sharif A. Judham, Baras, Wadah, Bahaq and Quwaba': A Study of Term and Concepts in "Al Qanun Fit Tib" of Ibn-Sina. JISHIM 2006; 5: 30-39.

3. Stefani MMdA. Challenges in the post genomic era for the development of tests for leprosy diagnosis. Rev Soc Bras Med Trop 2008; 41: 89-94.

4. Sidhu SS. Phage display in pharmaceutical biotechnology. Curr Opin Biotech 2000; 11(6): 610616.

5. Kerr-Pontes LRS, Montenegro ACD, Barreto $M L$, Werneck GL, Feldmeier $H$. Inequality and leprosy in Northeast Brazil: an ecological study. Int J Epidemiol 2004; 33(2): 262-269.

6. Modlin RL. The innate immune response in leprosy. Curr Opin Immunol 2010; 22(1): 48-54.

7. Aseffa A, Brennan P, Dockrell H, Gillis $T$, Hussain R, Oskam L, Richardus JH. Report on the first meeting of the IDEAL (Initiative for Diagnostic and Epidemiological Assays for Leprosy) consortium held at Armauer Hansen Research Institute, ALERT, Addis Ababa, Ethiopia on 24-27 October 2004. Lepr Rev 2005; 76(2): 147-159.

8. Menendez A, Scott JK. The nature of target-unrelated peptides recovered in the screening of phagedisplayed random peptide libraries with antibodies. Anal biochem 2005; 336(2): 145-157.

9. Vodnik M, Zager U, Strukelj B, Lunder M. Phage display: selecting straws instead of a needle from a haystack. Molecules 2011; 16(1): 790-817.

10. Ardekani LS, Gargari SLM, Rasooli I, Bazl MR, Mohammadi M, Ebrahimizadeh W, Bakherad H, Zare $H$. A novel nanobody against urease activity of Helicobacter pylori. Int J Infect Dis 2013; 17(9): e723e728.

11. Sidhu SS, Fairbrother WJ, Deshayes K. Exploring protein-protein interactions with phage display. Chembiochem 2003; 4(1): 14-25.

12. Burritt JB, DeLeo FR, McDonald CL, Prigge JR, Dinauer MC, Nakamura M, Nauseef WM, Jesaitis AJ. Phage Display Epitope Mapping of Human Neutrophil Flavocytochrome b558. Identification of two juxtaposed extracellular domains. J Biol Chem 2001; 276(3): 2053-2061.

13. Yu L, Yu PS, Yee Yen, Mui E, McKelvie JC, Pham TPT, Yap YW, Wong WQ, Wu J, Deng $W$, et al. Phage display screening against a set of targets to establish peptide-based sugar mimetics and molecular docking to predict binding site. Bioorg med chem 2009; 17(13): 4825-4832.

14. Bakherad H, Gargari SLM, Rasooli I, RajabiBazl M, Mohammadi M, Ebrahimizadeh W, Mousavi GGargari S, Rajabibazl M, Safaee Ardekani L, Zare H. In vivo neutralization of botulinum neurotoxins serotype $E$ with heavy-chain camelid antibodies (VHH). Mol biotech 2013; 55(2): 159-167.

15. Li $Y$, Ning $Y$, Wang $Y$, Peng $D$, Jiang $Y$, Zhang L, Long $M$, Luo J, Li M. Mimotopes selected with a neutralizing antibody against urease $B$ from Helicobacter pylori induce enzyme inhibitory antibodies in mice upon vaccination. BMC biotechnol 2010; 10(1): 84.

16. Ebrahimizadeh W, Rajabibazl M. Bacteriophage Vehicles for Phage Display: Biology, Mechanism, and Application. Curr microb 2014; 1-12.

17. Ebrahimizadeh W, Gargari SM, Rajabibazl M, Ardekani $L S$, Zare $H$, Bakherad $H$. Isolation and characterization of protective anti-LPS nanobody against $V$. cholerae 01 recognizing Inaba and Ogawa serotypes. Appl microbiol biotechnol 2013; 97(10): 4457-4466.

18. Manoutcharian K, Díaz-Orea A, Gevorkian G, Fragoso G, Acero G, González E, De Aluja A, Villalobos N, Gómez-Conde E, Sciutto E. Recombinant bacteriophage-based multiepitope vaccine against< 
i> Taenia solium</i> pig cysticercosis. Vet Immunol Immunopathol 2004; 99(1): 11-24.

19. Tur MK, Sasse S, Stocker M, Djabelkhir K, Huhn M, Matthey B, Gottstein C, Pfitzner T, Engert A, Barth S. An anti-GD2 single chain Fv selected by phage display and fused to Pseudomonas exotoxin $A$ develops specific cytotoxic activity against neuroblastoma derived cell lines. Int J Mol Med 2001; 8: $579-584$

20. Irving MB, Pan O, Scott JK. Random-peptide libraries and antigen-fragment libraries for epitope mapping and the development of vaccines and diagnostics. Curr Opin Chem Biol 2001; 5(3): 314-324.

21. Al-Bukhari T, Tighe $P$, Todd I. An immuno-precipitation assay for determining specific interactions between antibodies and phage selected from random peptide expression libraries. J Immunol Methods 2002; 264(1): 163-171.

22. Bradford MM. A rapid and sensitive method for the quantitation of microgram quantities of protein utilizing the principle of protein-dye binding. Anal Biochem 1976; 72(1): 248-254.
23. van Wezenbeek PMGF, Hulsebos TJM, Schoenmakers JGG. Nucleotide sequence of the filamentous bacteriophage M13 DNA genome: comparison with phage fd. Gene 1980; 11(1-2): 129-148.

24. Kurdi FN, Handojo I, Agoesni I, Dahlan YP. Amino acid sequence of $B$ cell epitope of $N$-terminal region of esat-6 mycobacterium lepra role as specific antigen for diagnosis of leprosy. Southeast Asian J Trop Med Public Health. 2010; 41(5): 1158-1163.

25. Monot M, Honoré $N$, Garnier T, Zidane $N$, Sherafi $D$, Paniz-Mondolfi A, Matsuoka M, Taylor GM, Donoghue HD, Bouwman A, et al. Comparative genomic and phylogeographic analysis of Mycobacterium leprae. Nat genet 2009; 41(12): 12821289.

26. Spencer JS, Dockrell HM, Kim HJ, Marques MAM, Williams DL, Martins MVSB, Martins MLF, Lima McBs, Sarno EN, Pereira GMB, et al. Identification of Specific Proteins and Peptides in Mycobacterium leprae Suitable for the Selective Diagnosis of Leprosy. J Immunol 2005; 175(12): 7930-7938. 